\title{
The first record of Anisus vorticulus (Troschel, 1834) (Gastropoda: Planorbidae) in Croatia?
}

\author{
LUBOŠ BERAN
}

Agency for Nature Conservation and Landscape Protection of the Czech Republic, Kokorinsko Protected Landscape Area Administration, Česká 149, CZ-27601 Mèlník,Czech Republic, e-mail: lubos.beran@nature.cz

\begin{abstract}
Beran L., 2009: The first record of Anisus vorticulus (Troschel, 1834) (Gastropoda: Planorbidae) in Croatia? - Malacologica Bohemoslovaca, 8: 70. Online serial at $<$ http://mollusca.sav.sk $>$ 14-December-2009.
\end{abstract}

\begin{abstract}
A threatened planorbid gastropod Anisus vorticulus (Troschel, 1834), listed in the EU Habitat Directive, was found in the Krka National Park in Croatia in August 2009. This find is the first known record at least in the western part of Croatia belonging to the Adriatic Sea drainage area.
\end{abstract}

\section{Keywords: Mollusca, Gastropoda, Anisus vorticulus, Croatia, Krka River}

\section{Introduction}

Anisus vorticulus (Troschel, 1834) is a small planorbid gastropod that inhabits mostly habitats with standing water. It is a Western Palaearctic species with its distribution centred in Eastern and Central Europe (TERRIER et al. 2006). The same authors considered populations of this snail to be widely separated and localised. On the recommendation of the Czech Republic, this species has been listed in the EU Habitat Directive since 2004 as a species of community interest requiring designation of special areas of conservation (Annex II) and strict protection (Annex IV). However, the distribution in many Member States or acceding countries is poorly known despite the fact that it is the basic element required for the preparation of conservation actions and management plans. In Croatia, which is one of the EU acceding countries, the recent status of Anisus vorticulus have been unknown and any data about its distribution are very useful.

\section{Results}

A small population of Anisus vorticulus was found in the Krka National Park in Croatia on $11^{\text {th }}$ August 2009. $A$. vorticulus occurred on aquatic vegetation in a slow flowing part (oxbow) of the Krka River upstream of the Skradinsky buk waterfalls near a bus stop (geographical coordinates, $\left.43^{\circ} 48^{\prime} 08^{\prime \prime} \mathrm{N}, 15^{\circ} 57^{\prime} 53^{\prime \prime} \mathrm{E}\right)$. Altogether seventeen living individuals and one empty conch of $A$. vorticulus were collected during washing vegetation using a metal sieve (kitchen strainer, diameter $20 \mathrm{~cm}$, mesh size $0.5-1 \mathrm{~mm}$ ) combined with a search of various substrates present in the site like stone, wood and vegetation of small site (about $1 \mathrm{~m}^{2}$ ) near a bank of the oxbow. One empty conch and one individual preserved in $70 \%$ ethanol are deposited in author's collection. A. vorticulus was recorded together with Theodoxus fluviatilis (Linnaeus, 1758), Bithynia tentaculata (Linnaeus, 1758), Valvata piscinalis (O.F. Müller, 1774), Stagnicola fuscus (C. Pfeiffer, 1821), and Physa fontinalis (Linnaeus, 1758). A. vorticulus, Ph. fontinalis, and Th. Aluviatilis were determined according to their conchs only, determination of other species were confirmed by dissection.

\section{Discussion}

TERrier et al. (2006), who compiled data about $A$. vorticulus, mentioned only one existing record from the former Yugoslavia situated along the Danube River. This site is Kovalski Sit (FrANK et al. 1990). Locality with this name was not identified (confusion with Kopacki Rit in Croatia or Koviljski Rit in Serbia?) and it was a reason for using the question mark in the title of this article. Nevertheless, this species probably occurs in Croatia at suitable sites along the Danube River, because it is known from a Hungarian part of the Danube floodplain in the Duna-Dráva National Park near the boundary beetween Hungary and Croatia (VARga \& Uherkovich 2002). Any other records of $A$. vorticulus are missing and the occurrence of this snail in the Krka National Park is the first known record at least in the western part of Croatia belonging to the Adriatic Sea drainage area. Since $A$. vorticulus was recorded during short-time research, it is probable that this species is more widely distributed in the Krka National Park and will be found in the case of more detailed research.

\section{References}

Frank C., Jungbluth J. \& Richnovszky A., 1990: Die Mollusken der Donau vom Schwarzwald bis zum Schwarzen Meer (Eine monographische Darstellung). - Aka- print, Budapest, 142 pp. Terrier A., Castella E., Falkner G. \& Killeen I.J., 2006: Species Account for Anisus vorticulus (Troschel, 1834) (Gastropoda: Planorbidae) a species listed in Annexes II and IV of the Habitat Directive. - Journal of Conchology, 39 (2): 193-205.

VArga A. \& Uherkovich Á., 2002: Malakológiai vizsgálatok a Duna-Dráva Nemzeti Park Gemenci Tájvédelmi Körzetében (Mollusca) [Malacological studies (Mollusca) in the Gemenc Landscape Protection Area of the Duna-Dráva National Park, South Hungary]. - Malakológiai Tájekoztató (Malacological Newsletter), 20: 107-141. 